\title{
ArcheoSciences
}

Revue d'archéométrie

\section{The jewellery from the casket of Maria Pia of Savoy, Queen of Portugal, produced at Castellani's workshop}

Les bijoux du coffret de Maria Pia de Savoie, Reine du Portugal,fabriqués à

l'atelier Castellani

Maria José Oliveira, Teresa Maranhas, Ana Isabel Seruya, Francisco A. Magro, Thierry Borel and Maria Filomena Guerra

\section{OpenEdition}

\section{Journals}

Electronic version

URL: http://journals.openedition.org/archeosciences/2308

DOI: 10.4000/archeosciences. 2308

ISBN: 978-2-7535-1598-7

ISSN: 2104-3728

Publisher

Presses universitaires de Rennes

\section{Printed version}

Date of publication: 31 December 2009

Number of pages: $265-270$

ISBN: 978-2-7535-1181-1

ISSN: 1960-1360

\section{Electronic reference}

Maria José Oliveira, Teresa Maranhas, Ana Isabel Seruya, Francisco A. Magro, Thierry Borel and Maria Filomena Guerra, «The jewellery from the casket of Maria Pia of Savoy, Queen of Portugal, produced at Castellani's workshop », ArcheoSciences [Online], 33 | 2009, Online since 10 December 2012 connection on 20 April 2019. URL : http://journals.openedition.org/archeosciences/2308 ; DOI 10.4000/archeosciences. 2308 


\title{
The jewellery from the casket of Maria Pia of Savoy, Queen of Portugal, produced at Castellani’s workshop
}

\author{
Les bijoux du coffret de Maria Pia de Savoie, Reine du Portugal, \\ fabriqués à l'atelier Castellani
}

\author{
Maria José Oliveira*, Teresa Maranhas**, Ana Isabel Seruya***, \\ Francisco A. Magro*****, Thierry Borel ${ }^{* * * * *}$ and Maria Filomena Guerra*****
}

\begin{abstract}
The casket of Queen Maria Pia of Savoy, belonging to the collection of the Palácio Nacional da Ajuda, contains a set of thirty-three pieces of gold jewellery in the archaeological style created by the Castellani workshop in Rome. This family of jewellers, fascinated by the ancient techniques of gold working, restored but also reproduced several antique pieces, giving rise to the emergence of the so-called 'archaeological jewellery', very popular in the $19^{\text {th }}$ century, using characteristic techniques of antique jewellery such as granulation, filigree, micro-mosaic and engraving of stones in intaglio.

The main purpose of this paper is to present the results of the analyses of the base metals used in the manufacture of the jewellery and also to identify the production techniques, such as mounting, joining and decoration, used by the Castellani workshop in making the jewellery for the casket of Queen Maria Pia of Savoy. For this purpose, portable equipment of examination and analysis was brought to the museum. The results obtained in situ show the use of standard wires and granules, as well as of three different base alloys. One element of a hairpin pair which appears to have originated from a different production is discussed.
\end{abstract}

Résumé : Le coffret offert à la Reine Maria Pia de Savoie, appartenant aux collections du Palácio Nacional da Ajuda, contient trente trois pièces d'orfevrerie en or fabriquées par les ateliers Castellani. L'attrait de cette famille d'orfevres pour les techniques de l'orfevrerie antique les a amenés à restaurer mais aussi à reproduire plusieurs pièces anciennes faisant émerger au XIX siècle le style archéologique. Pour fabriquer leurs bijoux, les Castellani ont utilisé différentes techniques caractéristiques de la décoration des pièces d'orfevrerie ancienne, dont la granulation, le filigrane, la gravure de gemmes en entaille et la mosä̈que sont des exemples.

Dans cette étude nous présentons les résultats analytiques obtenus pour la composition des alliages utilisés dans la fabrication des pièces du coffret de la Reine Maria Pia ainsi que la description des techniques de production des objets - montage, assemblage, décoration - utilisées par les Castellani. À cette fin, des équipements portables d'examen et analyse ont été transportés au musée pour effectuer une étude in situ. Les résultats obtenus montrent l'utilisation de fils et granules de forme homogène et de trois alliages d'or. Un élément d'une paire d'épingles à cheveux, dont la production semble être différente, est discuté.

Keywords: jewellery, gold, analysis, Castellani, XRF.

Mots-clés : bijoux, or, analyses, Castellani, FX.

* Laboratório de Conservação e Restauro José de Figueiredo, Rua das Janelas Verdes 37, 1249-018, Lisboa, Portugal. (mariaoliveira@imc-ip.pt)

** Palácio Nacional da Ajuda, Largo da Ajuda, 1349-021, Lisboa, Portugal. pnajuda.(teresamaranhas@imc-ip.pt)

*** Centro de Física Atómica da Universidade de Lisboa, Av. Prof. Gama Pinto 2, 1649-003, Lisboa, Portugal. (anaseruya@gmail.com)

**** Academia Portuguesa da História e Associação Numismática de Portugal, Rua Angelina Vidal 40, 1170-020, Lisboa, Portugal

***** Laboratoire du Centre de Recherche et de Restauration des Musées de France, UMR171 CNRS, 14, quai François-Mitterrand, 75001 Paris, France.(maria.guerra@culture.gouv.fr) 


\section{INTRODUCTION}

The work of the Castellani family on antique jewellery gave rise to the 'archaeological style' jewellery that was very much in fashion during the $19^{\text {th }}$ century (Rudoe, 1986). In 1862 , they created one of their most famous productions, the jewellery casket, a good example of their skill, to be offered by the people of Rome to Queen Maria Pia of Savoy when she married King Luís I of Portugal.

The casket of Queen Maria Pia of Savoy (PNA, inv. 52545/A), held in the Palácio Nacional da Ajuda in Lisbon, Portugal, contains 33 pieces of jewellery produced by the Castellani workshop in the archaeological style. This type of jewellery emerged as a consequence of the excavations of archaeological tombs in Egypt, Greece and Italy, namely in Pompeii, at the end of the $18^{\text {th }}$ century. The techniques used by Etruscan goldsmiths (between the $7^{\text {th }}$ and $3^{\text {rd }}$ centuries $\mathrm{BC})$ greatly fascinated the Castellani family. Their curiosity and innovation led them to the revival of the ancient production techniques, particularly granulation and filigree, in which the Etruscans were experts.

The casket of the Palácio Nacional da Ajuda, created in the $19^{\text {th }}$ century, is probably a copy of an original example that Augustus, the first emperor of Rome, offered to his daughter on the occasion of her marriage. The jewels of this casket are meant to replicate the needs of a noble woman's toilette in ancient times. Some objects are stylistically very close to known ancient pieces of jewellery, others contain ancient gold and silver coins. These items are inspired by the iconography and mythological themes of ancient Rome: a medallion, two pairs of cufflinks, a stickpin, three rings, a laurel diadem, fourteen hairpins, two pairs of earrings, a bulla pendant, a brooch, a hair comb, a bracelet with Roman coins, and a chain with Greek coins (Fig. 1).

Castellani did not stamp all these pieces in a regular way. His maker's punch - monogram "CC" within a cartouche, or just "CC" without the cartouche - appears only on some items.

The ancient coins used by Castellani in these jewels were classified and dated individually, their date of issue ranging from the $5^{\text {th }}$ century BC to the $4^{\text {th }}$ century AD. The chain has seven Greek silver coins, issued from the $5^{\text {th }}$ to the $3^{\text {rd }}$ century BC; the bracelet has seven Roman silver coins from the $1^{\text {st }}$ century $\mathrm{BC}$, and the bulla pendant has two Roman coins, one in gold from the $2^{\text {nd }}$ century $\mathrm{AD}$, and one in bronze, from the $4^{\text {th }}$ century AD.

In spite of the work dedicated to $19^{\text {th }}$ century jewellery and more specifically to the work of the Castellani (Donati, 2006; Soros and Walker, 2004; Formigli, 1993), very few studies include analytical information on the techniques and

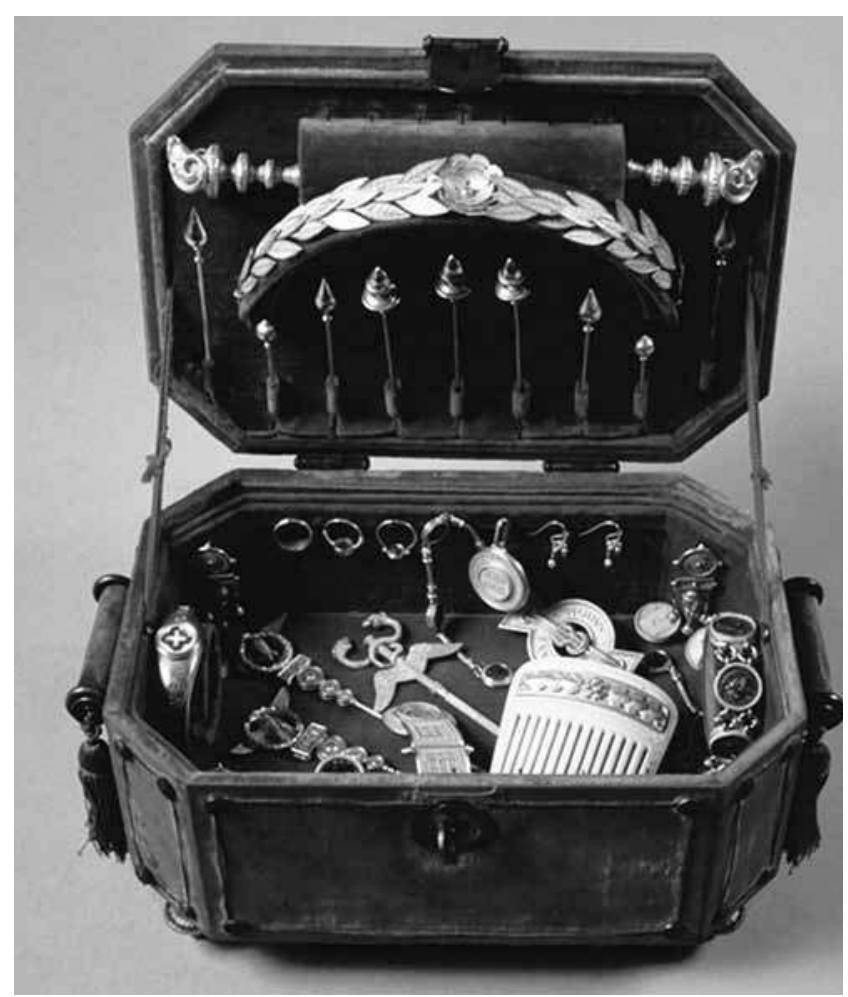

Figure 1: (See colour plate) Casket with the jewels of Queen Maria Pia of Savoy.

Figure 1 : (Voir planche couleur) Coffret avec les joyaux de la Reine Maria Pia de Savoie.

alloys used by the goldsmiths (Cesareo and Von Hase, 1976; Ogden, 2004; Swaddling et al., 1991). The aim of this work is to identify and classify the techniques used at Castellani's workshop for the production of archaeological style jewellery by studying the casket offered to Maria Pia with nondestructive analytical-based techniques carried out in situ. The results obtained in this work should provide references for the identification of the assumed interventions of these goldsmiths on different ancient gold items.

\section{Methods}

All the jewellery items were studied in situ at the Palácio Nacional da Ajuda. The items were examined with a portable optical microscope and an X-radiography system, and analysed with a portable X-Ray Fluorescence (XRF) equipment. All these methods are non-invasive (Guerra and Calligaro, 2003).

The study of the techniques of decoration and production used by Castellani in the execution of Maria Pia of Savoy's jewellery was performed using an optical microscope Leica 
MZ6, with a magnification of up to 40x, a digital camera, Leica DC200, and a digital X-radiography system ArtXRay, NTB GmbH (X-Ray generator Y.MBS/160-F01).

The portable XRF was an E.I.S. Srl system, model XRS38, with W anode $(0.40 \mathrm{~mA}, 30 \mathrm{kV})$. The spectrum treatment and the quantification of the results were carried out using the QXAS 3.6 program developed by the International Atomic Energy Agency. The results have been normalized to $100 \%$. A set of ternary gold alloy standards were used to calibrate the equipment. Their composition is $75 \% \mathrm{Au}$, $12.5 \% \mathrm{Ag}, 12.5 \% \mathrm{Cu}$, and $75.0 \% \mathrm{Au}, 6.0 \% \mathrm{Ag}, 19.0 \%$ $\mathrm{Cu}$, respectively.

\section{Results}

\section{Production techniques}

The examination of the jewels under the optical microscope allowed the identification of four types of wire used in the manufacture of the filigree decoration patterns: plain circular section wire, rope or cable pattern wire (obtained by twisting two plain wires together), beaded wire and helicoidal wire. The plain circular section wires are of two different diameters: on average, 0.49 and $1.00 \mathrm{~mm}$, respectively. The cable wires vary in diameter, averaging between $0.15 \mathrm{~mm}$ and $0.72 \mathrm{~mm}$. The beaded wire has an average diameter of $0.72 \mathrm{~mm}$, and the helicoidal wire of $0.53 \mathrm{~mm}$.

Modern wires were produced by drawing, which means passing the wires through the holes of a draw-plate in order to obtain the required diameter, contrary to what is typically assumed for ancient wire. Drawn wires can be recognised by the seams on the surface of the wire. Those seams are longitudinal and parallel to the axis of the wire. All the wires used in the production of the jewellery contained in Maria Pia's casket were produced with drawn wire. Figure 2 shows the striation on the surface of one wire.

In addition to filigree, the jewellery contained in the casket of Queen Maria Pia of Savoy presents patterns of granulation and evidence of other decorative techniques, such as micro-mosaic and engraving. The granules are of two different sizes: the smaller ones have an average diameter of $1.50 \mathrm{~mm}$, while the larger ones have an average diameter of about $3.00 \mathrm{~mm}$.

Some of the pieces show repetition of motifs, such as the leaves on the diadem and the hair comb, which were executed by stamping each individual leaf with a matrix.

The hairpins with ram's heads show skilled decoration, in which a roughened surface effect is obtained by chasing. This technique was not used for any of the other pieces.

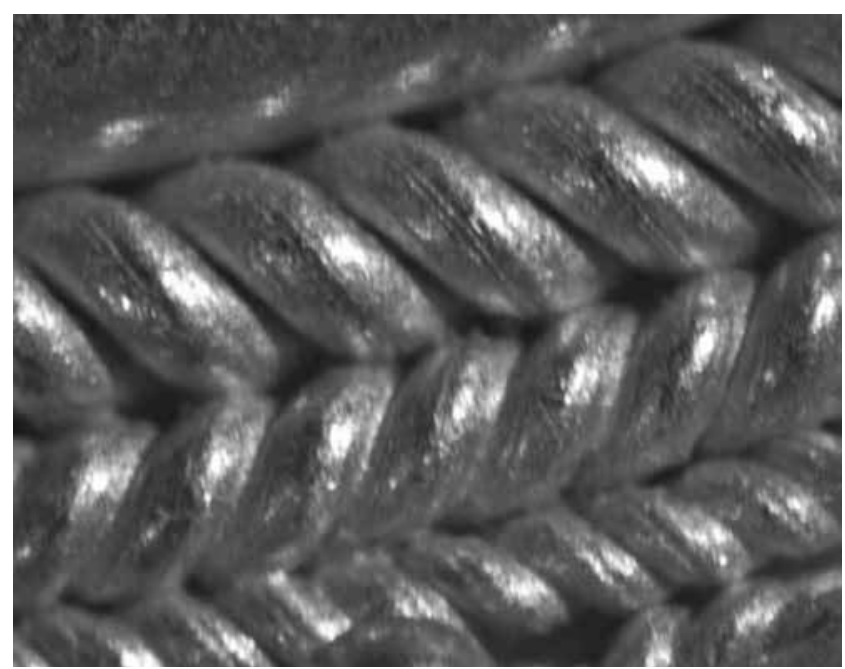

Figure 2: Detail of the seams on the surface of the wire (PNA, inv. 52563).

Figure 2 : Détail des sillons sur la surface du fil (PNA, inv. 52563).

All the elements of the earrings and pins were executed by a skilled goldsmith, using the same techniques and the same decorative elements. However, one pair of hairpins with an imperial eagle and the inscription $S P Q R$ presents significant differences in terms of technical execution between the two elements of the pair. The decoration of these pieces is essentially obtained through the application of cable patterned wire and small gold foils in the form of leaves. The ropes consist of two wires twisted together (Fig. 3). Only one of

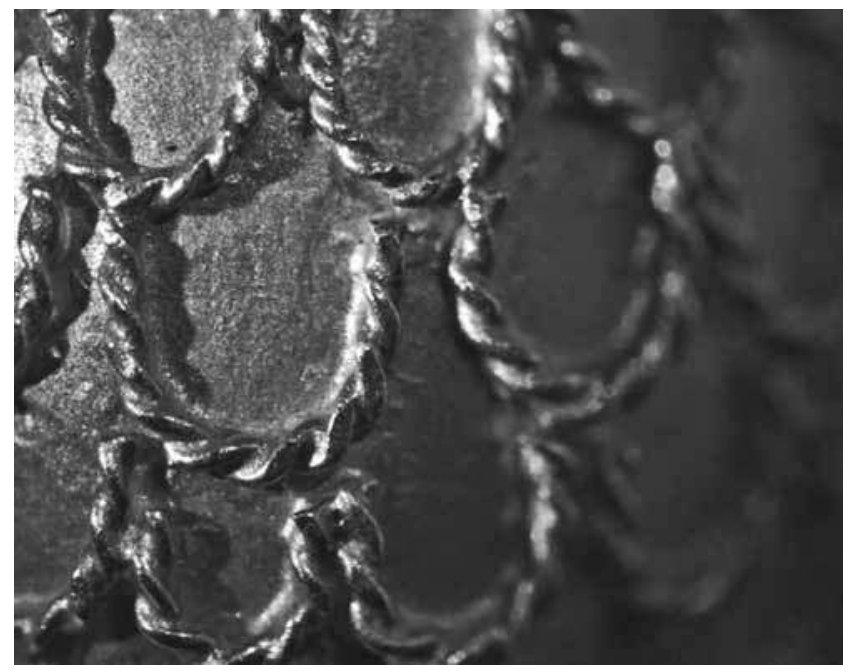

Figure 3: Details of the filigree decoration of the pair of hairpins with the imperial eagle.

Figure 3 : Détails de la décoration en filigrane d'une paire d'épingles à cheveux avec l'aigle impériale. 
the pins has a few granules fused to it (PNA, inv. 52570). On both hairpins, the inscription was applied using plain circular section wire, although the construction of the letters differs from one element of the pair to the other, as shown by the images obtained under the optical microscope for letters 'Q' and 'R' (Fig. 4). The letters shown in Figures 4e and $4 \mathrm{f}$ are of better quality. However, not only the letters are technically different between the two elements of the pair. The crowns of leaves and the paws of the eagles, for example, also differ between the two pins (Fig. 5). Again, the elements in Figures $5 \mathrm{c}$ and $5 \mathrm{~d}$ demonstrate a higher level of technical execution than those in Figures $5 \mathrm{a}$ and $5 \mathrm{~b}$.
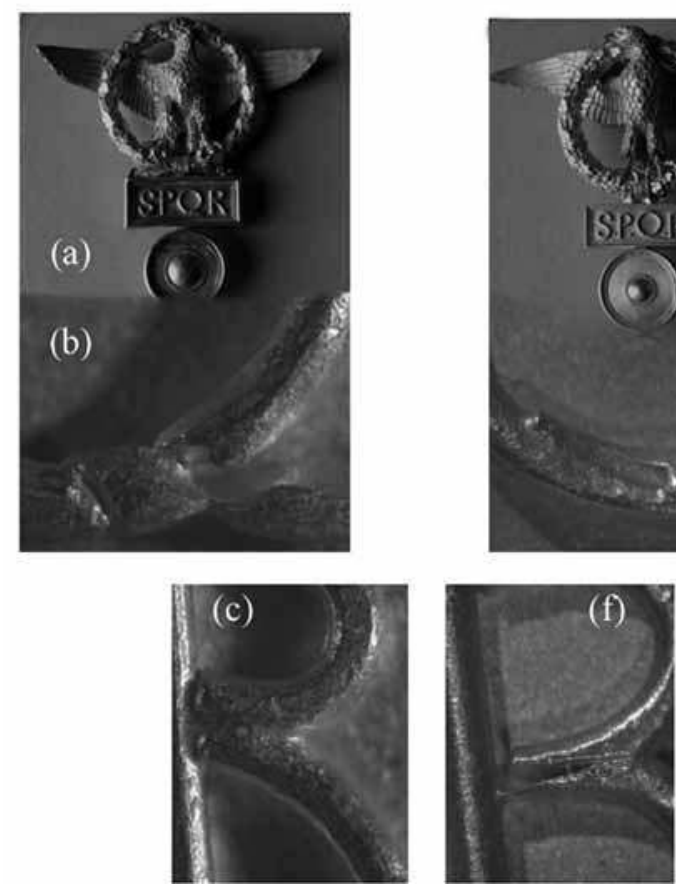

Figure 4: (See colour plate) Details of the pair of hairpins with the imperial eagle.

Figure 4 : (Voir planche couleur) Détails d'une paire d'épingles à cheveux avec l'aigle impériale.
The radiographic images of these two pieces (Fig. 6) highlight the differences between them (wings, head and paws of the eagles, drums, etc.). The differences in radiographic density are related to the different thickness of the metal foils used in the execution of each piece.

\section{Base-alloys}

Table 1 presents the results obtained by portable XRF for all the individual jewellery items belonging to Maria Pia's casket. We were able to identify three distinct groups according to the alloys used. The first two groups include the jewellery with the simpler decoration, while the third group includes the jewellery with more complex decoration.

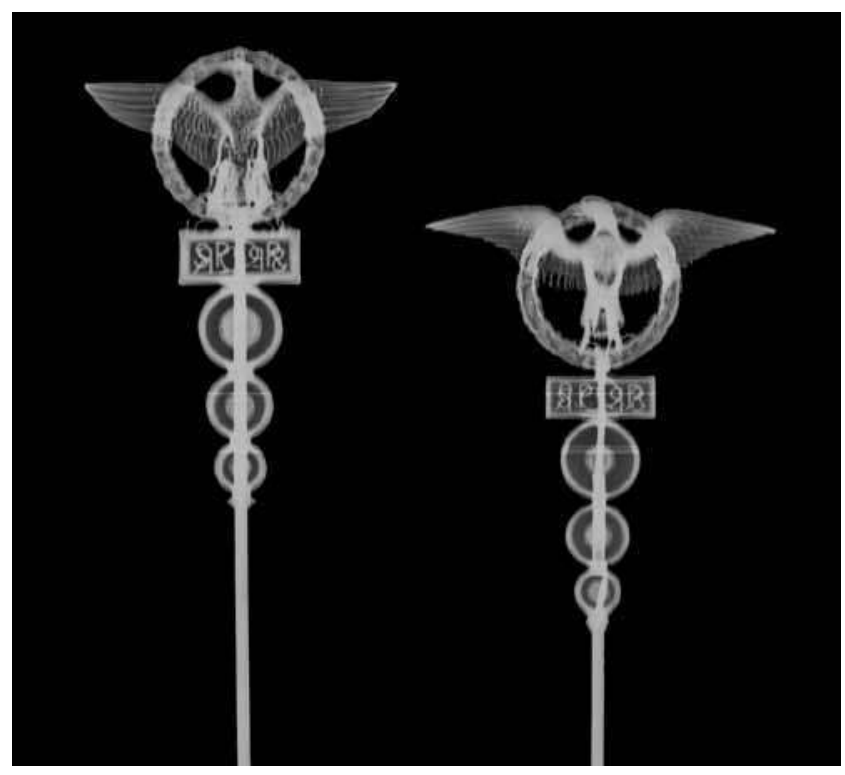

Figure 6: (See colour plate) X-radiography of the pair of hairpins with the imperial eagle.

Figure 6: (Voir planche couleur) Radiographie aux rayons $X$ d'une paire d'épingles à cheveux avec l'aigle impériale.

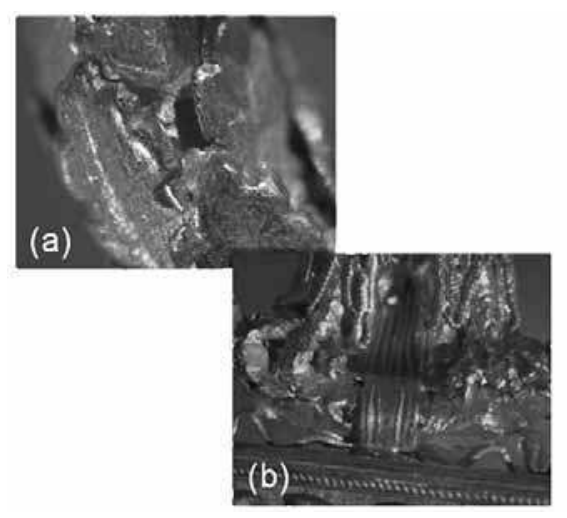

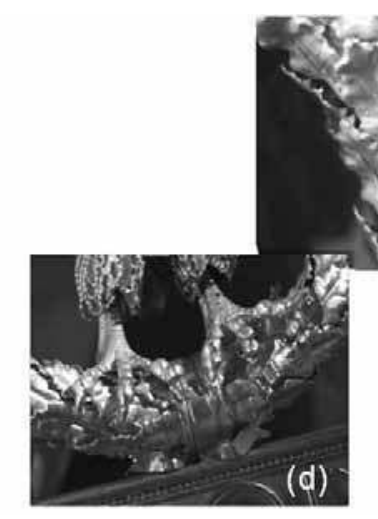

(d)
Figure 5: (See colour plate) Details of the pair of hairpins with the imperial eagle.

Figure 5 : (Voir planche couleur) Détails d'une paire d'épingles à cheveux avec l'aigle impériale. 
Table 1: Characterization of the different alloys by XRF.

Tableau 1 : Caractérisation des différents alliages par XRF.

\begin{tabular}{|c|c|c|c|c|}
\hline & \multirow{2}{*}{ Jewellery items } & \multicolumn{3}{|c|}{ Composition } \\
\hline & & $\mathrm{Au}(\%)$ & $\operatorname{Ag}(\%)$ & $\mathrm{Cu}(\%)$ \\
\hline \multirow{8}{*}{ 完 } & Cufflink ROMA/AMOR (PNA, inv. 52685) & 90.6 & 8.4 & 1.1 \\
\hline & Cufflink ROMA/AMOR (PNA, inv. 52686) & 92.7 & 6.7 & 0.6 \\
\hline & Ring with lapis lazuli intaglio (PNA, inv. 52547) & 93.1 & 6.5 & 0.4 \\
\hline & Stickpin (PNA, inv. 52475) & 92.6 & 6.2 & 1.2 \\
\hline & Hairpin pointed head (PNA, inv. 52552) & 90.0 & 9.1 & 0.9 \\
\hline & Hairpin acorn head (PNA, inv. 52555) & 85.0 & 10.7 & 4.4 \\
\hline & Chain with Greek coins (PNA, inv. 52572) & 90.8 & 8.2 & 1.0 \\
\hline & Hairpin with imperial eagle (PNA, inv. 52571) & 93.6 & 3.3 & 3.1 \\
\hline \multirow{11}{*}{$\stackrel{\sim}{\stackrel{2}{0}}$} & Ring Mercvril (PNA, inv. 52546) & 86.7 & 11.6 & 1.7 \\
\hline & Diadem (PNA, inv. 52548) & 86.9 & 11.7 & 1.4 \\
\hline & Hairpin spherical head (PNA, inv. 52549) & 85.9 & 12.3 & 1.7 \\
\hline & Hairpin spherical head (PNA, inv. 52550) & 86.7 & 11.9 & 1.4 \\
\hline & Hairpin pointed head (PNA, inv. 52551) & 88.1 & 10.6 & 1.3 \\
\hline & Earrings (PNA, inv. 52558) & 88.4 & 10.7 & 1.0 \\
\hline & Earrings (PNA, inv. 52559) & 88.1 & 10.8 & 1.1 \\
\hline & Earrings crotalia (PNA, inv. 52560) & 88.0 & 10.5 & 1.5 \\
\hline & Earrings crotalia (PNA, inv. 52561) & 87.9 & 10.7 & 1.4 \\
\hline & Hair comb (PNA, inv. 52565) & 88.5 & 9.8 & 1.7 \\
\hline & Bracelet with Roman coins (PNA, inv. 52568) & 88.1 & 10.6 & 1.4 \\
\hline \multirow{7}{*}{$\stackrel{n}{\text { a }}$} & Cufflink EROS (PNA, inv. 52443) & 79.1 & 17.3 & 3.6 \\
\hline & Ring with cornelian intaglio (PNA, inv. 52545) & 82.7 & 13.9 & 3.4 \\
\hline & Pendant bulla (PNA, inv. 52563) & 80.7 & 16.6 & 2.7 \\
\hline & Brooch NODVS HERCVLEVS (PNA, inv. 52564) & 82.8 & 15.2 & 2.1 \\
\hline & Hairpin pin ram's head (PNA, inv. 52566) & 80.4 & 17.1 & 2.5 \\
\hline & Hairpin pin ram's head (PNA, inv. 52567) & 78.7 & 18.9 & 2.4 \\
\hline & Hairpin with imperial eagle (PNA, inv. 52570) & 83.9 & 13.5 & 2.6 \\
\hline
\end{tabular}

In contrast to all the other pairs of jewels - for example, the pair of ram's head pins, with the composition $79.6 \% \mathrm{Au}$, $18.0 \% \mathrm{Ag}$ and $2.4 \% \mathrm{Cu}$, the pair of hairpins with the imperial eagle also shows a difference in composition between the two elements. The second pin (Fig. 4d) has an average percentage of gold of approximately $94 \%$, fitting the first group, while the other pin (Fig. 4a) has an average percentage of gold of about $84 \%$, with higher silver contents, fitting the third group.

The jewellery in the first group has a composition similar to the one of the fibulae in the set of copies made by Castellani and kept at the Villa Giulia museum in Rome (Cesareo and Von Hase, 1976). The limited number of analysis results available from objects in the Villa Giulia does not match our results.

\section{Discussion and Conclusion}

The decorative elements of almost all the jewellery included in Maria Pia's casket are identical in type and dimension. This may be the result of a continuous 'assembly line' type of production undertaken in the Castellani workshop, which is typical of $19^{\text {th }}$ century manufacturing methods.

The gold/metal alloys used in the fabrication of these objects have gold contents ranging from 73 to $98 \%$, silver contents between 2 and 24\%, and copper contents from 1 to $13 \%$. However, the higher amounts of silver and copper are only present in a few particular objects. Although all the items in Queen Maria Pia of Savoy's casket have been made by Castellani, we can now ascertain that different base alloys were used. 
All the jewellery denotes a high manufacturing skill. In spite of the different alloys employed in the manufacture of this jewellery, only the hairpin with the imperial eagle presents major differences relative to the other element of the pair, and to the entire suite of jewellery.

The jewellery collection of the Palácio Nacional da Ajuda includes other items in the archaeological style, namely a gold necklace with 23 beetles and a parure of gold filigree with cornelian settings (a bracelet, a bar-brooch and a pair of earrings), made by an unknown goldsmith. In the future, we intend to submit these pieces to a similar study in order to compare the results with those of the analyses of the Castellani jewellery.

\section{References}

Cesareo, R. and Von Hase, F.W., 1976. Analisi di ori etruschi del VII sec. a.C. con uno strumento portatile che impiega la tecnica fluorescenza X eccitata da radioisotope. Atti dei Convegni Lincei 11: 259-296.

Donati, M., 2006. Les bijoux Campana et le fonds Castellani du Museo Artistico Industriale di Roma, in F. Gaultier, C.
Metzger (eds.), Trésors antiques, bijoux de la collection Campana. Paris, Musée du Louvre, 103-107.

Formigl, E., 1993. Einige Fälschungen antiken Goldschmucks im 19. Jahrhundert. Archäologischer Anzeiger 3: 299-332.

Guerra, M.F. and Calligaro, T., 2003. The analysis of gold: manufacture technologies and provenance of the metal. Measurement in Science and Technology 14: 1527-1537.

Ogden, J., 2004. Revivers of the lost art: Alessandro Castellani and the quest for classical precision, in S.W. Soros, S. Walker (eds.), Castellani and Italian Archaeological Jewelry. New York, Bard Graduate Center, 181-200.

Rudoe, J., 1986. Elizabeth Barrett Browning and the taste for Archaeological-Style Jewelry. Philadelphia Museum of Art Bulletin 83(353): 22-23.

Soros, S.W. and WALKER, S. (eds.), 2004. Castellani and Italian Archaeological Jewelry. New York, Bard Graduate Center.

Swaddling, J., Oddy, A. and MeEks, N., 1991. Etruscan and Other Early Gold Wire from Italy. Society of Jewellery Historians 5: 7-21. 


\section{South America: \\ GOLd STUdies IN THE NEW World \\ Amérique du Sud : \\ ÉTUDES DES ORS DU NOUVEAU MONDE}


